\title{
BUNDLE-BRANCH BLOCK UNDER VOLUNTARY CONTROL
}

\author{
BY \\ G. E. BAUER \\ From the Cardio-Vascular Clinic, Sydney Hospital, Sydney, N.S.W., Australia \\ Received May 13, 1963
}

Bundle-branch block can no longer be regarded as a static condition always associated with an organic lesion situated in one of the main bundles of the ventricular conduction system, as suggested by the early experiments of Eppinger and Rothberger $(1909,1910)$ and by Lewis and Rothschild (1915). A great amount of work, based on histological, electrocardiographic, and hæmodynamic studies, has revealed some of the immense complexity of the subject.

In the course of a survey of 167 patients with bundle-branch block (Bauer, 1964), many examples of transient and intermittent bundle-branch block were discovered. In one patient the conduction defect could be made to appear and disappear by simple manœuvres. Subsequently, during the following 12 months, four further examples of voluntary control of bundle-branch block were discovered: these five patients, whose case histories are summarized in Table $I$ and reported in detail below, are the subject of this report.

The concept that bundle-branch block, in some instances, may be under voluntary control and can be induced and abolished at will is of obvious practical as well as theoretical interest.

TABLE I

Summary of Five Patients with Left Bundle-Branch Block under Voluntary Control

\begin{tabular}{|c|c|c|c|c|c|c|}
\hline Case No. & $\begin{array}{l}\text { Sex and age } \\
(y r .)\end{array}$ & Diagnosis & $\begin{array}{c}\text { Conduction } \\
\text { defect }\end{array}$ & $\begin{array}{l}\text { Electrocardiogram } \\
\text { showing normal } \\
\text { conduction }\end{array}$ & $\begin{array}{l}\text { Method of inducing } \\
\text { normal conduction }\end{array}$ & $\begin{array}{c}\text { Critical } \\
\text { heart } \\
\text { rate/min }\end{array}$ \\
\hline 1 & M.55 & $\begin{array}{l}\text { Ischæmic heart } \\
\text { disease }\end{array}$ & LBBB & $\begin{array}{l}\text { Anterior } \\
\text { myocardial } \\
\text { infarction }\end{array}$ & $\begin{array}{l}\text { Deep inspiration } \\
\text { and breath holding } \\
\text { Carotid sinus } \\
\text { stimulation } \\
\text { Pharmacological } \\
\text { agents }\end{array}$ & $71-74$ \\
\hline 2 & M.39 & $\begin{array}{c}\text { Ischæmic and } \\
\text { hypertensive } \\
\text { heart disease }\end{array}$ & LBBB & $\begin{array}{l}\text { Anterior and } \\
\text { posterior wall } \\
\text { ischæmia }\end{array}$ & $\begin{array}{l}\text { Deep inspiration and } \\
\text { breath holding }\end{array}$ & $50-60$ \\
\hline 3 & M.42 & $\begin{array}{l}\text { Ischæmic heart } \\
\text { disease }\end{array}$ & LBBB & $\begin{array}{l}\text { Antero-septal } \\
\text { infarction }\end{array}$ & $\begin{array}{l}\text { Deep inspiration and } \\
\text { breath holding }\end{array}$ & $60-62$ \\
\hline 4 & M.48 & $\begin{array}{l}\text { Hypertensive } \\
\text { heart disease } \\
\text { and chronic } \\
\text { glomerulo- } \\
\text { nephritis }\end{array}$ & LBBB & $\begin{array}{l}\text { Left ventricular } \\
\text { hypertrophy; } \\
\text { ischæmia }\end{array}$ & $\begin{array}{l}\text { Carotid sinus } \\
\text { stimulation }\end{array}$ & $62-68$ \\
\hline 5 & M.52 & $\begin{array}{l}\text { Ischæmic heart } \\
\text { disease }\end{array}$ & LBBB & Normal & $\begin{array}{l}\text { Deep inspiration and } \\
\text { breath holding }\end{array}$ & $\begin{array}{l}\text { Indeter- } \\
\text { minate }\end{array}$ \\
\hline
\end{tabular}

LBBB = left bundle-branch block. 


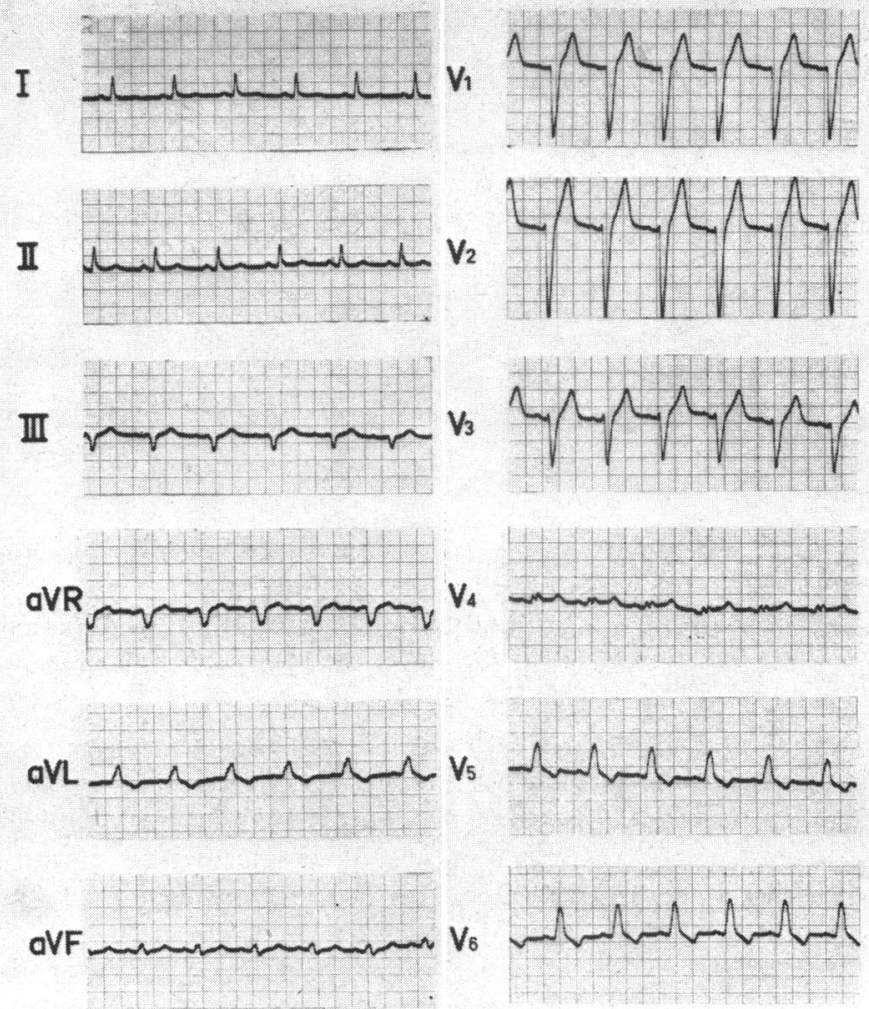

Fig. 1.-Case 1, November 1961. Intermittent left bundle-branch block.

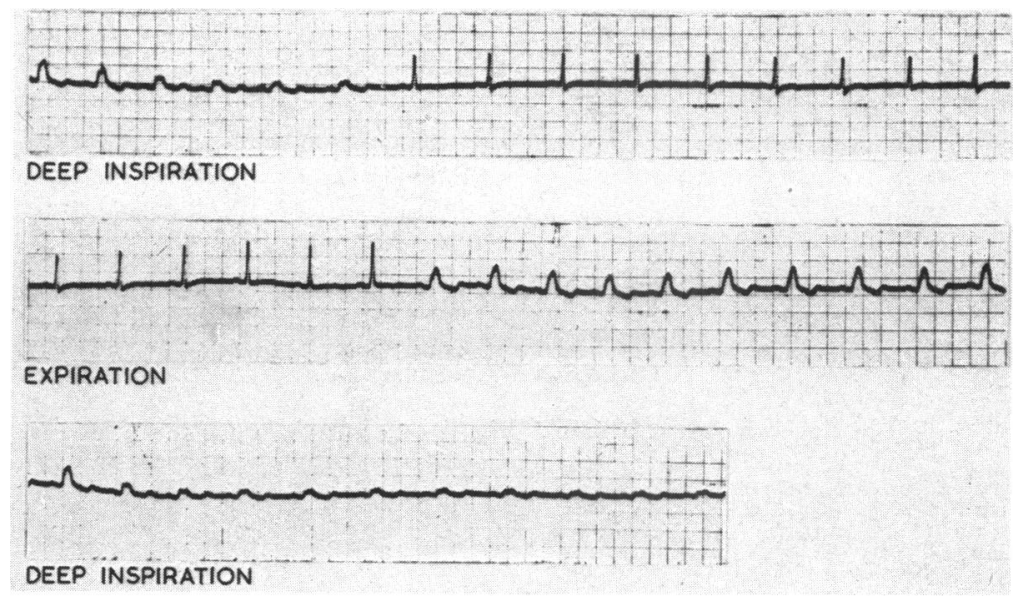

Fig. 2.-Case 1, November 1961. Effect of deep breathing; lead V6, continuous record. 


\section{CASE RePORTS}

Case 1. A man aged 55 years had been subject to left-sided ischæmic chest pain, radiating to the left arm and shoulder, since July 1960. A cardiogram in September 1960 revealed limited anterior wall infarction with raised ST segments and sharply inverted T waves on præcordial leads V2 to V5. In September 1961, while on an overseas trip, he was found to be suffering from transient left bundle-branch block, and on at least one occasion, according to the report received, it had been possible to re-establish normal conduction after oxygen inhalation.

When the patient was first examined in November 1961 he was in regular sinus rhythm, and the blood pressure was $130 / 80 \mathrm{~mm}$. $\mathrm{Hg}$. The heart showed no signs of enlargement, and the heart sounds were normal. The cardiogram (Fig. 1) showed intermittent left bundle-branch block; the standard bipolar limb leads showed left axis deviation with slight flattening of $\mathrm{T}$ waves in lead $\mathrm{I}$; and unipolar leads demonstrated left bundle-branch block. Several simple manœuvres were tried to influence the conduction defect. Light exercise, insufficient to influence the heart rate, produced no change. Carotid sinus pressure, although slowing the heart rate from 88 to 75 beats a minute, also failed to influence the conduction defect. Deep inspiration and breath holding, however (Fig. 2), in addition to positional lowering of the widened QRS complexes, led to a progressive increase of the RR interval from $0.64 \mathrm{sec}$. (94 beats a minute) to $0.84 \mathrm{sec}$. (71 beats a minute) with the establishment of normal intraventricular conduction at the critical level of $0.82 \mathrm{sec}$. (73 beats a minute). With resumption of breathing the heart rate once again accelerated and bundle-branch block reappeared. With the next deep inspiration normal conduction was re-established at a cycle length of $0.82 \mathrm{sec}$. and remained in spite of gradual acceleration until the RR interval shortened to $0.70 \mathrm{sec}$. when bundle-branch block once again appeared.

These observations were repeated six weeks later in December 1961 (Fig. 3). The control limb leads with cycle lengths of 0.64 to $0.72 \mathrm{sec}$. showed left bundle-branch block. With deep inspiration and breath

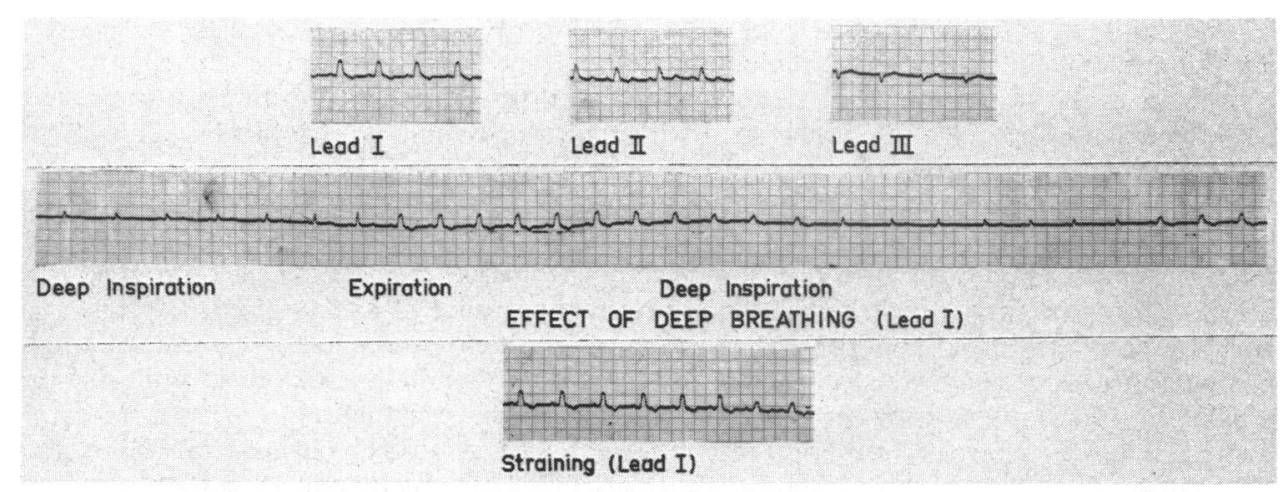

Fig. 3.-Case 1, December 1961. Effect of deep breathing.

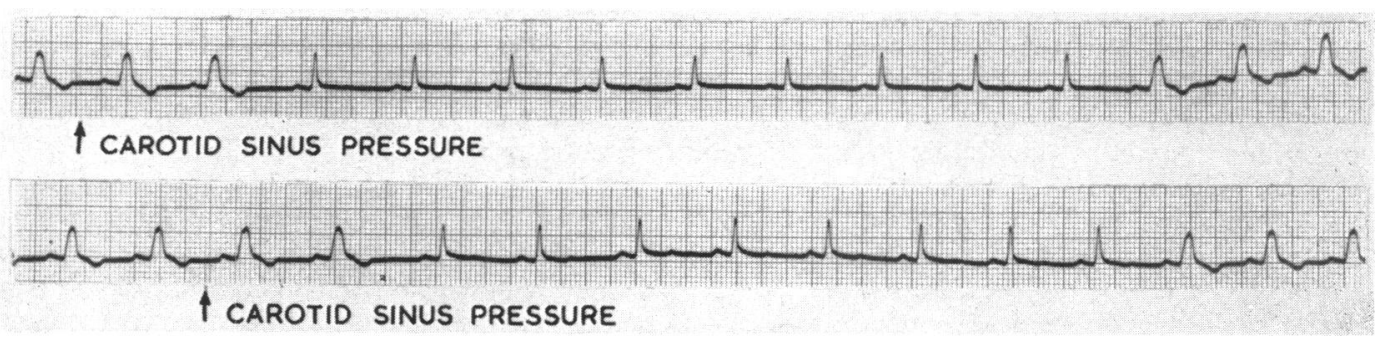

Fig. 4.-Case 1, March 1962. Effect of carotid sinus pressure; lead I, continuous record. 
TABLE II

Effect of Physiological and Pharmacological Stimuli on Heart Rate and Cardiac Conduction IN CASE 1

\begin{tabular}{|c|c|c|c|c|c|c|c|}
\hline \multicolumn{4}{|c|}{ Stimulus } & \multicolumn{2}{|c|}{ Before test } & \multicolumn{2}{|c|}{ Response } \\
\hline & & & & Rate/min. & Conduction & Rate/min. & Conduction \\
\hline $\begin{array}{l}\text { Physiological } \\
\text { Deep inspiration } \\
\text { Rapid respiration } \\
\text { Exercise } \quad . . \\
\text { Valsalva } \quad \text {. } \\
\text { Carotid sinus pressu } \\
\text { Eye-ball pressure }\end{array}$ & $\begin{array}{c} \\
\cdots \\
\cdots \\
\ldots \\
\ldots \\
\ldots\end{array}$ & $\begin{array}{l}\cdots \\
\cdots \\
\cdots \\
\cdots \\
\cdots\end{array}$ & $\begin{array}{l}\cdots \\
\cdots \\
\cdots \\
\cdots \\
\cdots\end{array}$ & $\begin{array}{l}79 \\
72 \\
66 \\
66 \\
79 \\
72\end{array}$ & $\begin{array}{l}\text { LBBB } \\
\text { Normal } \\
\text { Normal } \\
\text { Normal } \\
\text { LBBB } \\
\text { LBBB }\end{array}$ & $\begin{array}{l}56 \\
83 \\
75 \\
75 \\
60 \\
65\end{array}$ & $\begin{array}{l}\text { Normal } \\
\text { LBBB } \\
\text { LBBB } \\
\text { LBBB } \\
\text { Normal } \\
\text { Normal }\end{array}$ \\
\hline \multicolumn{3}{|c|}{ 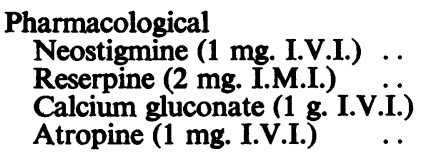 } & $\begin{array}{l}\ldots \\
\cdots \\
\cdots \\
.\end{array}$ & $\begin{array}{l}72 \\
75 \\
78 \\
65\end{array}$ & $\begin{array}{l}\text { LBBB } \\
\text { LBBB } \\
\text { LBBB } \\
\text { Normal }\end{array}$ & $\begin{array}{l}62 \\
58 \\
68 \\
88\end{array}$ & $\begin{array}{l}\text { Normal } \\
\text { Normal } \\
\text { Normal } \\
\text { LBBB }\end{array}$ \\
\hline
\end{tabular}

LBBB = left bundle-branch block

holding the heart rate dropped to 68 a minute, cycle length 0.88 sec., and normal conduction was reestablished. With expiration the heart rate increased and when the RR interval dropped from $0.74 \mathrm{sec}$. to $0.68 \mathrm{sec}$. bundle-branch block reappeared. This was repeated with similar results in the next respiratory cycle. Straining increased the heart rate to 100 a minute, cycle length $0.60 \mathrm{sec}$., with persistence of bundlebranch block.

Three months later, further cardiographic investigations were carried out. The basic pattern was once again left bundle-branch block and deep inspiration, which on this occasion slowed the pulse rate only to 86 beats a minute, and failed to correct the conduction defect. Firm pressure on the right carotid sinus produced a drop in the heart rate to 71 beats a minute with the re-establishment of normal conduction (Fig. 4). After release the pulse rate accelerated with return of bundle-branch block. This phenomenon could be repeatedly demonstrated.

The patient was subsequently admitted to Sydney Hospital where further physiological and pharmacological studies were carried out (Table II). Neostigmine bromide and reserpine significantly slowed the heart rate with temporary disappearance of bundle-branch block. Intravenous calcium gluconate had a similar effect. Atropine accelerated the heart rate with reappearance of the conduction defect.

All investigations seemed to confirm that the type of conduction was solely determined by the heart rate. Any stimulus increasing the heart rate caused the return of bundle-branch block, while any procedure that succeeded in sufficiently slowing the rate re-established normal conduction.

The patient is now being treated with oral reserpine in an attempt to keep his pulse rate below the critical level of 72 beats a minute. His general condition has remained satisfactory; he is leading a very active life subject to only occasional attacks of ischæmic chest pain. When he was last seen recently bundle-branch block could still be made to come and go at will.

Case 2. Hypertension was discovered in July 1953 when the patient, aged 30 years, was rejected for life assurance. In December 1955 he became aware of tightness in the throat while polishing his car but did not seek medical attention. When seen in May 1956 he complained of slight headache, dizziness, nausea and occasional discomfort in the throat on severe exertion. On examination his pulse was regular and the blood pressure was $210 / 130 \mathrm{~mm}$. $\mathrm{Hg}$; there was left ventricular enlargement and triple heart rhythm; and hypertensive retinopathy was present with a few recent hæmorrhages.

The cardiogram (Fig. 5) showed intermittent left bundle-branch block. In the first lead recorded (Fig. 5A), the initial complexes displayed left bundle-branch block and then changed suddenly to normal conduction which persisted in leads II, III, and unipolar limb leads, revealing changes of posterior wall ischæmia. By the time the chest leads were recorded left bundle-branch block had reappeared and is seen in V1 and V2. In lead V3 normal conduction was again established and remained to V6 showing symmetrical $T$ wave inversion in V3 and V4. In view of the unusual pattern observed, the tracing was immediately repeated (Fig. 5B). Lead I still showed normal conduction: however, in lead II bundle-branch block 


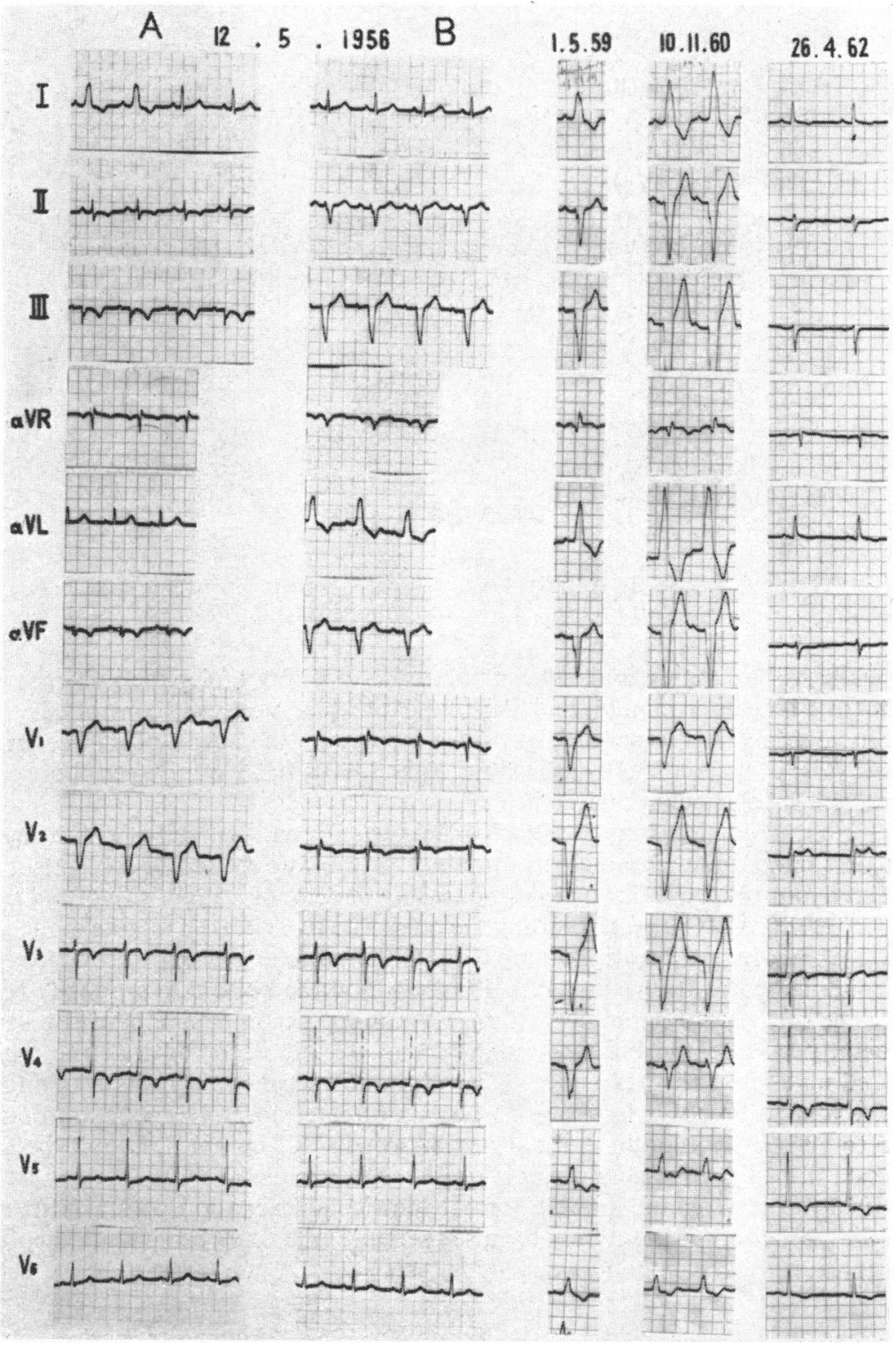

Fig. 5.-Case 2. Electrocardiograms showing intermittent left bundle-branch block.

reappeared and remained in lead III and the unipolar limb leads. The left bundle-branch block complexes completely concealed the changes of posterior wall ischæmia, which were obvious in the same leads in the previous tracing. In lead V1 normal conduction was re-established and continued to the end of the record.

Full investigations, including intravenous pyelography, aortography, and phentolamine test failed to demonstrate any underlying disease to account for hypertension. Subsequent cardiograms including those recorded in May 1959 and November 1960 showed the apparently stable pattern of left bundle-branch block. On that latter date his pulse rate was 77 beats a minute and his blood pressure was $210 / 140 \mathrm{~mm}$. $\mathrm{Hg}$. Although he remained practically symptom free, it was decided to reduce his blood pressure, and this was satisfactorily accomplished with the aid of guanethidine and hydrochlorothiazide. 


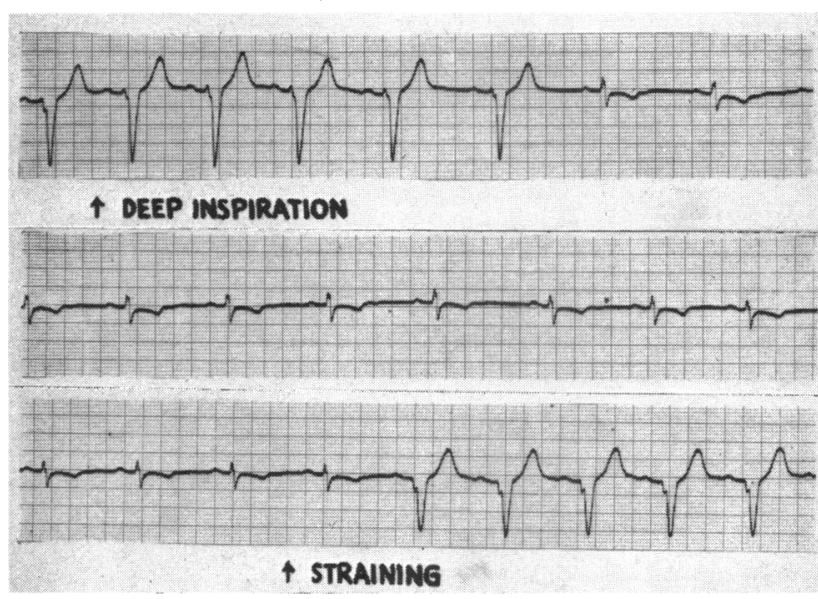

FIG. 6.-Case 2, August 1962. Effect of deep breathing and straining; lead II, continuous record.

In April 1962 while still taking these drugs his pulse rate, possibly under the influence of guanethidine, had dropped to 58 to 61 beats a minute, and the blood pressure was well controlled. The cardiogram showed normal intraventricular conduction, with some increase in the height of the $\mathbf{R}$ waves in left ventricular surface leads. The $R$ wave in V4 was $31 \mathrm{~mm}$. compared with $21 \mathrm{~mm}$. when first seen in May 1956, suggesting progressive left ventricular enlargement.

In August 1962 intermittent left bundle-branch block was found. Initially, with a heart rate of 58 to 62 beats a minute, left bundle-branch block was present; as the rate slowed to 54 beats a minute, normal conduction reappeared and persisted throughout the tracing in spite of a slight rise of pulse rate to 60 beats a minute. Straining which had the effect of raising the pulse rate to 68 beats a minute induced bundle-branch block. With deep inspiration and breath holding (Fig. 6) the pulse rate dropped to 51 beats a minute with return to normal conduction. After release of held inspiration the pulse rate gradually rose to 60 beats a minute without change of the cardiographic pattern. Straining, accompanied by a rise in pulse rate to 67 beats a minute, again produced the bundle-branch block. It was observed that the type of ventricular conduction depended mainly on the heart rate: when the rate exceeded 60 beats a minute bundle-branch block was present, when the rate was less than 55 beats a minute, normal conduction dominated. In the transition zone, 55 to 60 beats a minute, normal or abnormal QRS complexes could be found depending on the previously established type of conduction.

In November 1962 the cardiogram showed normal ventricular excitation with a heart rate of 58 to 62 beats a minute. Mild exercise, sufficient only to raise the pulse rate to 67 beats a minute, failed to alter the pattern of normal intraventricular conduction.

Case 3. A 42-year-old man was first seen in November 1962. Four years earlier, on Christmas Day 1958, he suffered myocardial infarction from which he made an uneventful recovery. In August 1962 he began to experience vague chest discomfort related to stress or laughter rather than exertion.

On examination no abnormal signs could be elicited. The weight was normal. The pulse was regular, and the blood pressure was $130 / 90 \mathrm{~mm}$. $\mathrm{Hg}$; there was no evidence of cardiac enlargement, and the heart sounds were normal. The serum cholesterol was within normal limits, $240 \mathrm{mg}$. $/ 100 \mathrm{ml}$.

The cardiogram (Fig. 7) showed intermittent left bundle-branch block: the normally conducted complexes revealed evidence of old antero-septal myocardial infarction. Bundle-branch block complexes were preceded by $R R$ intervals of $0.88-1.00 \mathrm{sec}$. (heart rate of $60-68$ beats a minute), normally conducted complexes were preceded by RR intervals of $0.96-1.18 \mathrm{sec}$. (heart rate of 51 to 62 beats a minute). The relation of the cycle length to the type of intraventricular conduction is graphically represented in Fig. 9. Accelerating the heart rate by straining and prolonged expiration invariably produced left bundle-branch block, and deep inspiration and breath holding slowed the heart rate and re-established normal conduction (Fig. 8). 


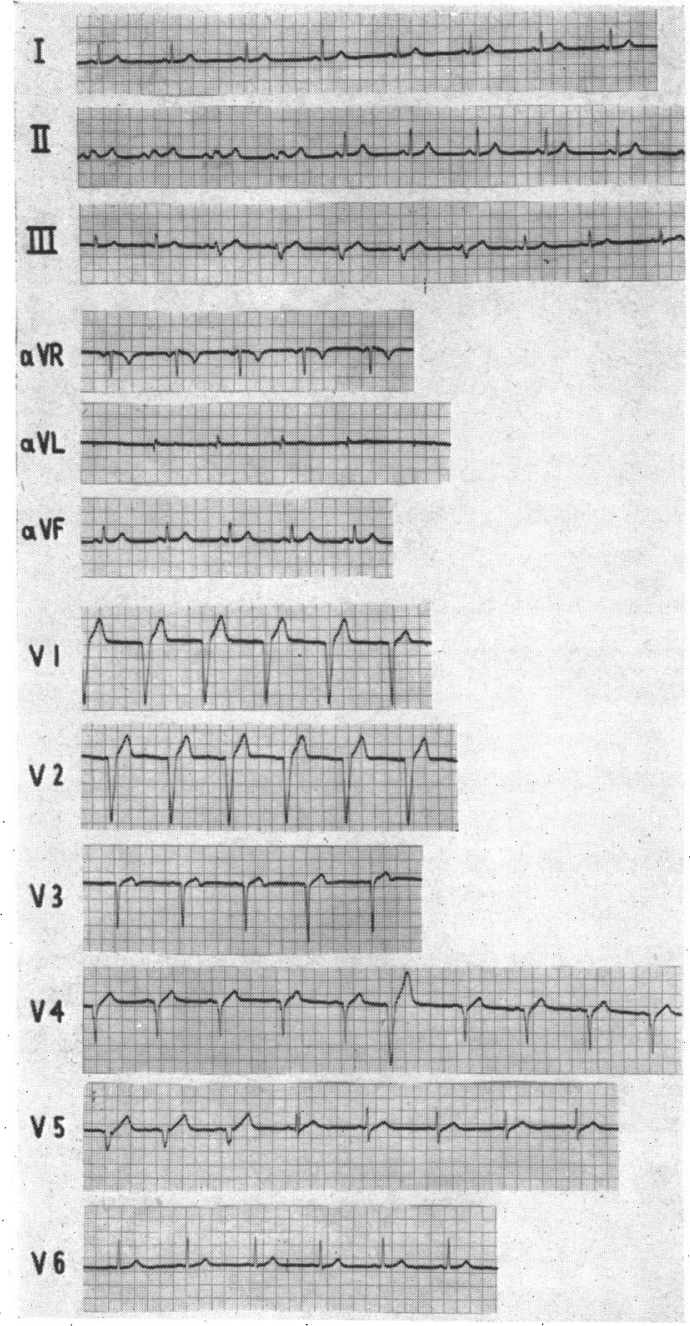

Fig. 7.-Case 3, November 1962. Intermittent left bundle-branch block.
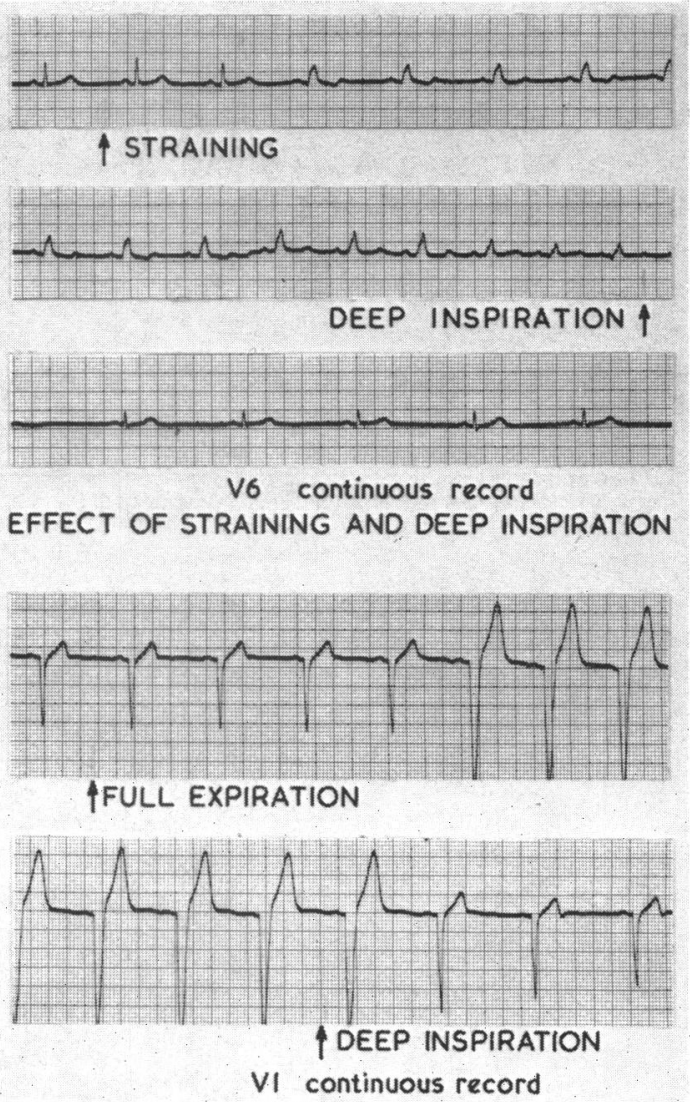

EFFECT OF EXPIRATION AND INSPIRATION

FIG. 8.-Case 3, November 1962. Effect of straining and deep breathing.

The patient was seen again in December 1962. During the control tracing the RR interval was 0:98 sec. or less (heart rate of 61 beats a minute or more), and the conduction pattern was that of left bundle-branch block. Altering the heart rate by the appropriate respiratory manœuvre once again allowed the voluntary induction and abolition of bundle-branch block.

Case 4. A 48-year-old man was first seen in December 1962. He had been found to suffer from hypertension and proteinuria during a life assurance examination in 1946 and was subsequently treated with a variety of hypotensive drugs. In January 1962 he developed a retinal vein thrombosis. An electrocardiogram taken at that time showed left ventricular hypertrophy and anterior myocardial ischæmia. In October 1962 left bundle-branch block was discovered. Apart from partial loss of vision in the left eye he was symptom free; and he denied any chest pain or undue breathlessness.

On examination his pulse was regular, and the blood pressure was $190 / 130 \mathrm{~mm}$. Hg. Cardiac enlargement was present with presystolic triple rhythm. Hypertensive retinopathy with exudates and hæmorrhages. in the left eye were detected. The urine contained a trace of protein. Full investigations revealed moderate impairment of renal function and findings compatible with a diagnosis of chronic glomerulonephritis. 


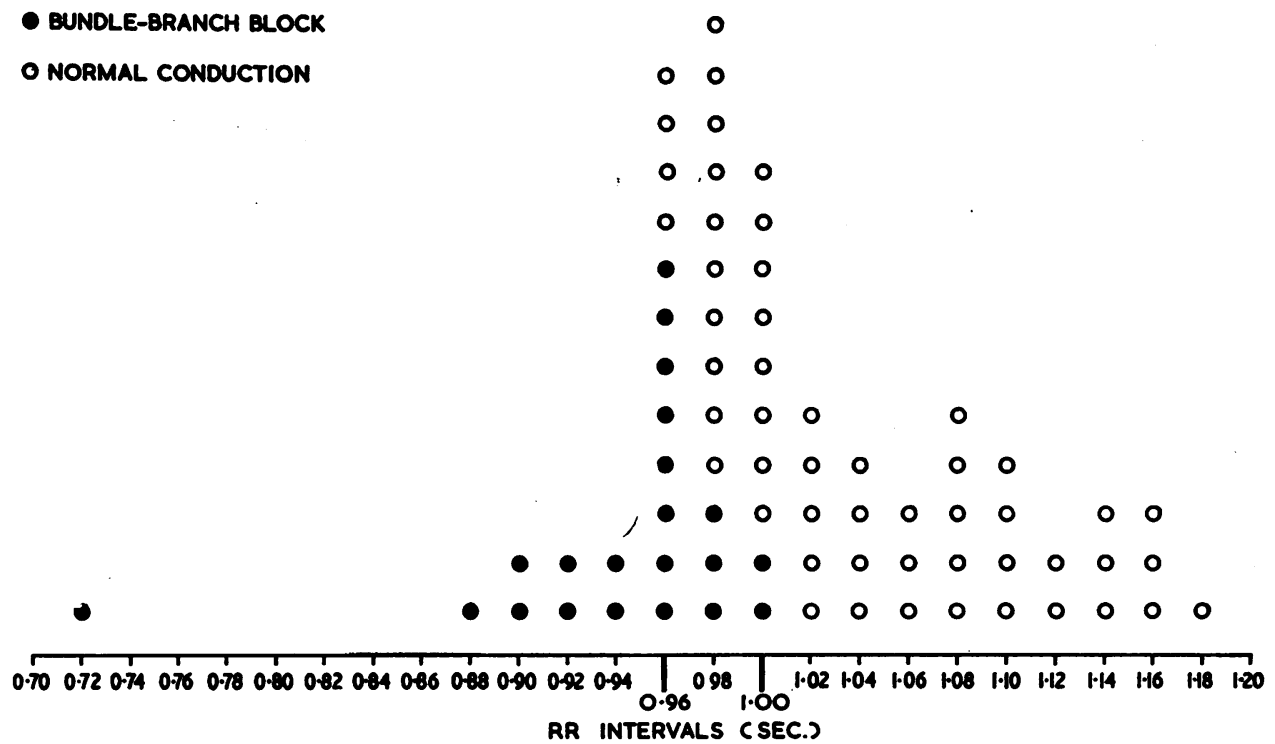

Fig. 9.-Case 3, November 1962. Relation of intraventricular conduction to RR intervals.

The electrocardiogram (Fig. 11) indicated left bundle-branch block, with complexes in lead II showing normal conduction: this was associated with a spontaneous increase in the $R R$ intervals from $0.84 \mathrm{sec}$. to $0.96 \mathrm{sec}$. Deep inspiration and breath holding produced an alteration in the QRS vector but only a very slight fall in the heart rate and failed to abolish the bundle-branch block. Right carotid sinus pressure, however, slowed the heart rate from 70 to 45 beats a minute with the disappearance of the conduction defect (Fig. 10). Variability in the width of the QRS complexes was observed: when bundle-branch block was present the QRS complexes were of $0.16 \mathrm{sec}$. duration, but after carotid sinus stimulation the complexes

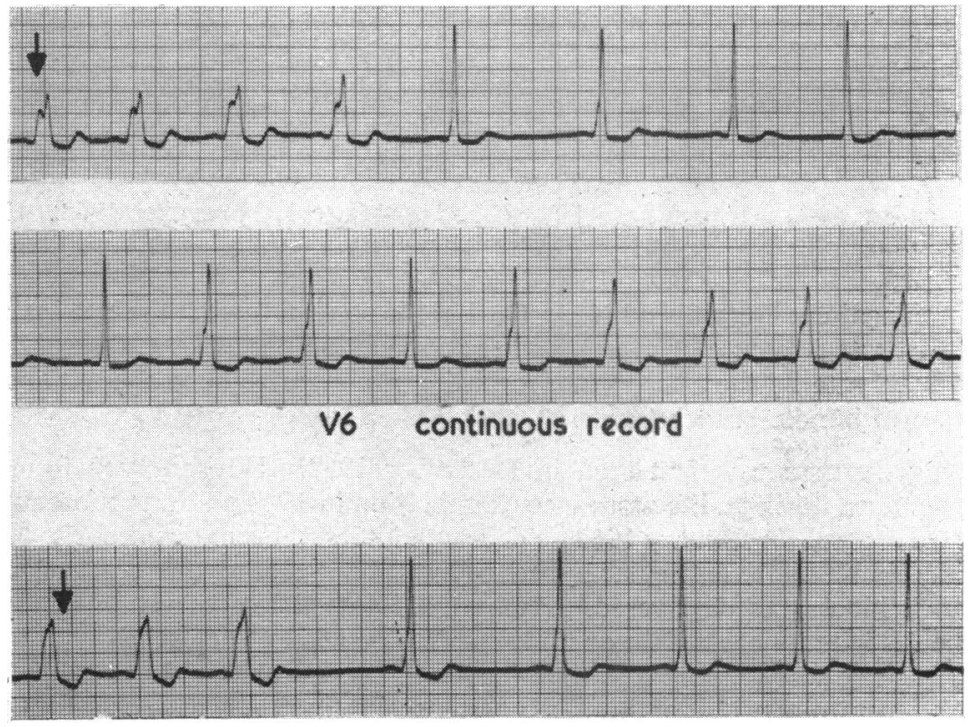

Fig. 10.-Case 4, December 1962. Effect of carotid sinus pressure (arrow). 
I

I

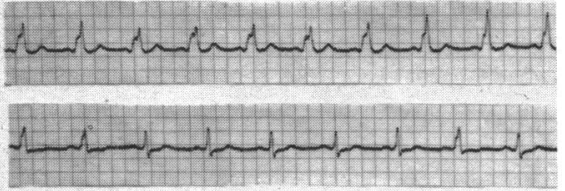

II

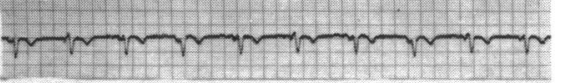

aVR

$a V L$

aVF

Y I

V2

V3

V4

V5

V6
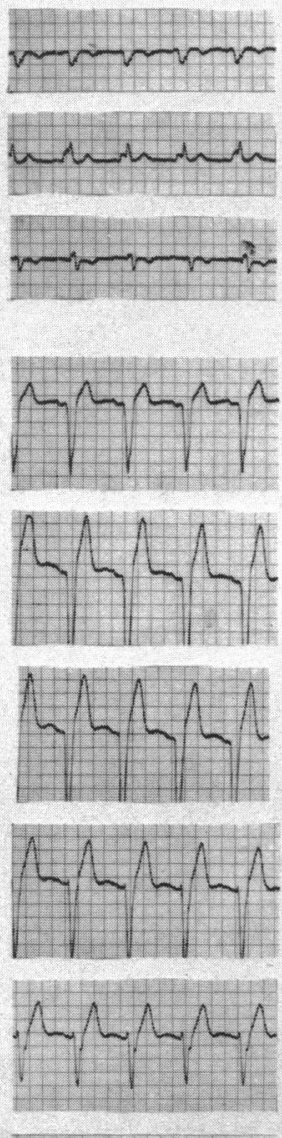

in inching

Fig. 11.-Case 4, December 1962. Left bundlebranch block with complexes showing normal intraventricular conduction in lead II. narrowed to $0 \cdot 12 \mathrm{sec}$. and then to $0 \cdot 10 \mathrm{sec}$. With the release of vagal stimulation the pulse rate accelerated and when the RR interval shortened to $0.96 \mathrm{sec}$. bundlebranch block reappeared. The first QRS complex after the reappearance of the conduction defect was $0.14 \mathrm{sec}$. in duration, but with further increase in heart rate it widened to $0.16 \mathrm{sec}$. The transition in this patient fromnormal to abnormal conduction presumably passed through a brief phase of incomplete left bundlebranch block. Subsequently, the full cardiogram was repeated with carotid sinus stimulation. The pattern of the normally conducted complexes revealed left ventricular hypertrophy and sharp ischæmic $T$ wave inversion in the chest leads.

The patient was studied again three months later with similar findings. The patient is now being treated with methyldopa and bendrofluazide, his blood pressure is moderately well controlled, and he continues to be fully active in his profession.

Case 5. A 52-year-old man complained, when first seen on January 7, 1963, of epigastric and retrosternal discomfort of nine months' duration. The description of his symptoms was compatible with, but by no means diagnostic of, cardiac ischæmia. An electrocardiogram taken two months earlier showed left bundle-branch block.

On examination he was slightly overweight. The pulse was regular at 75 beats a minute. The blood pressure was $150 / 80 \mathrm{~mm}$. Hg. There was no evidence of cardiac enlargement, and the heart sounds were normal. The cardiogram revealed left bundle-branch block. With deep inspiration the pulse rate dropped to 60 a minute and after repeated attempts three complexes with normal intraventricular conduction were recorded (Fig. 12). The normally conducted beats showed no abnormality. Carotid sinus pressure failed to slow the heart rate significantly or to abolish the bundle-branch block.

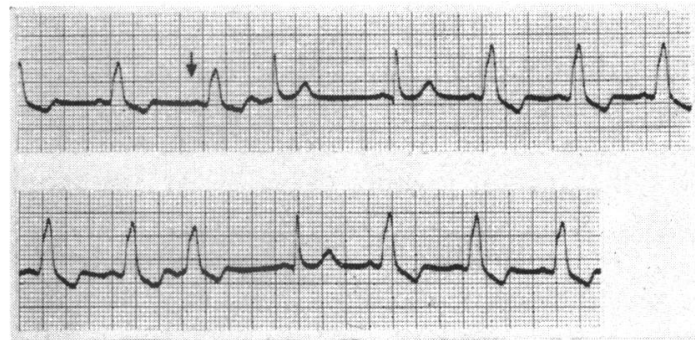

Fig. 12.-Case 5, January 1963. Effect of deep breathing (arrow); lead V6.

\section{Discussion}

The original concept of bundle-branch block, following the classical experiments of Eppinger and Rothberger $(1909,1910)$, was that of a permanent intraventricular conduction defect caused by a pathological process interrupting the ventricular excitation pathway. The reversibility of the 
cardiographic pattern associated with such a conduction disturbance was suggested by Lewis (1913) when he reported the first instance of transient bundle-branch block in a 32-year-old bookbinder suffering from rheumatic aortic regurgitation. In the same year Mathewson (1913) published electrocardiograms from a 57-year-old man with congestive heart failure showing in one continuous record varying ventricular complexes, some with bundle-branch block patterns and others with normal intraventricular conduction.

In 1931 Herrmann and Ashman collected 10 cases of transient bundle-branch block from the published reports including the one reported by Sir Thomas Lewis, to which they added 5 cases of their own. They also mentioned "three most unusual cases in which we have been able to record sudden transitions from complete bundle-branch block to normal intraventricular conduction time for transient periods as a result of indirect vagus effects." They found in one of their patients suffering from a reticulosis and bundle-branch block that deep inspiration would re-establish normal conduction with sudden transition as the heart rate dropped from 75 to 65 beats a minute. Exercise led to a reappearance of bundle-branch block.

Since then reports of a number of cases have been published where the disappearance and reappearance of bundle-branch block was noted (Comeau, Hamilton, and White, 1938; Vesell, 1941; Eichert, 1946; Sandberg et al., 1951 ; Bergquist and Hällen, 1956; Dressler, 1959; Wallace and Laszlo, 1961; Hallhagen, 1961; Miller, 1962). Levine (1960) drew attention to the practical value of slowing the heart rate in the diagnosis of myocardial infarction in patients with left bundle-branch block and recommended it as a useful procedure.

It has long been known that alterations in the heart rate are of significance in the appearance and disappearance of bundle-branch block (Daniélopolu and Danulesco, 1921). Electrocardiograms have been published in which changes from normal to abnormal conduction occurred from one cardiac cycle to another, related to an increase or decrease of heart rate of only one or two beats a minute (Vesell, 1941).

In the majority of instances retardation of the heart rate favours normal intraventricular conduction while acceleration facilitates bundle-branch block. Slowing of the heart rate can be accomplished in a number of ways. Deep inspiration (Herrmann and Ashman, 1931; Bergquist and Hällen, 1956), carotid sinus massage (Wallace and Laszlo, 1961; Hallhagen, 1961), and resumption of the recumbent posture (Bergquist and Hällen, 1956) have been shown to abolish bundlebranch block. Pharmacological agents that reduce the heart rate and have been successful in re-establishing normal conduction include ergotamine tartrate (Bergquist and Hällen, 1956) reserpine (Case 1), oxygen (Baker, 1930), amyl nitrite (von Mentzingen, 1934; Comeau et al., 1938), calcium gluconate (Wallace and Laszlo, 1961), and molar sodium lactate (Wallace and Laszlo, 1961). The recently discovered adrenergic beta-receptor blocking compound pronethalol ("alderlin") (Black and Stephenson, 1962) is at present being investigated as a diagnostic agent. The control of heart failure by digitalis (Comeau et al., 1938) and thyrotoxicosis by surgery (Packard and Graybiel, 1950) may be accompanied by disappearance of bundle-branch block.

Acceleration of heart rate induces or leads to the reappearance of bundle-branch block. Full expiration, straining, or some other form of Valsalva manœuvre (Wallace and Laszlo, 1961), assumption of the upright posture (Vesell, 1941; Bergquist and Hällen, 1956; Wallace and Laszlo, 1961), and exercise (Herrmann and Ashman, 1931; Eichert, 1946; Sandberg et al., 1951; Wallace and Laszlo, 1961; Hallhagen, 1961) have frequently been shown to precipitate bundle-branch block. Amongst the pharmacological agents with a similar action are quinidine (Barker, Johnston, and Wilson, 1943), procaine amide (Wallace and Laszlo, 1961), atropine (Eichert, 1946), potassium (Wallace and Laszlo, 1961), and amyl nitrite (Eichert, 1946; Wallace and Laszlo, 1961). Some of these drugs may act by directly depressing intraventricular conduction.

Rarely, changes in the heart rate have produced paradoxical effects. Dressler (1959) reported two cases of transient bundle-branch block appearing during slowing of the heart rate and after gagging: he postulated that increase in vagal tone may have a vaso-constrictor effect on the soronary circulation and thus induce an ischæmic mechanism, but there is no confirmatory evidence 
for this hypothesis. Wallace and Laszlo (1961) reported that forceful pressure of the carotid sinus, accompanied by marked bradycardia, not only terminated but also consistently induced bundlebranch block in their patient, a 46-year-old man who 14 months earlier had suffered from myocardial infarction.

The practical importance of being able to abolish intraventricular conduction defect at will is best demonstrated in the diagnosis of myocardial infarction complicated by left bundle-branch block. It has been generally accepted, since the writings of Wilson et al. (1944), that cardiac infarction complicated by right bundle-branch block is readily recognizable, but cardiac infarction complicated by left bundle-branch block rarely presents typical electrocardiographic features of myocardial infarction. The characteristic $Q$ waves fail to appear owing to alterations in the activation of the interventricular septum and the repolarization abnormalities are frequently obscured by secondary changes accompanying left bundle-branch block. Less difficulty is experienced during the acute phase when suggestive ST segment and T wave changes may be present, or with massive involvement of the septum, especially the lower one-third, resulting in the appearance of pathological $Q$ waves in leads I, aVL, V5, and V6.

The possibility of recognizing myocardial infarction during periods of normal conduction in transient and intermittent bundle-branch block has been mentioned by several authors (Somerville and Wood, 1949; Shearn and Rytand, 1953). In a recent survey of bundle-branch block, eight patients (including Case 1 and Case 2 of the present series) with transient and intermittent conduction defects were discovered in whom the electrocardiographic diagnosis of myocardial infarction or ischæmia became possible during periods of normal conduction (Bauer, 1964). At that time it was realized that in Case 1 the conduction defect was under voluntary control, subsequently it was recognized that it could be abolished and induced at will also in Case 2. Since then, within a few months, three similar patients were discovered. There is reason to believe that such cases are not isolated curiosities and that a deliberate search will reveal many similar instances of reversible bundle-branch block. They are more likely to be discovered if cardiograms are frequently repeated in patients with left bundle-branch block and if such simple manœuvres as deep inspiration with breath holding and carotid sinus massage are carried out routinely. Occasionally improvement of cardiac function and slowing of the heart rate following a period of rest and control of heart failure may facilitate unmasking of bundle-branch block. The place of pharmacological agents in the re-establishment of normal conduction has yet to be evaluated.

The underlying mechanism of transient bundle-branch block remains a topic for speculation. In 1923, Carter and Dieuaide postulated that a few intact fibres of the conducting bundle were carrying on the normal excitation process under favourable conditions. However, a minor local circulatory deficiency might be responsible for failure of the surviving fibres and thus precipitate the conduction defect. It is also likely that transient bundle-branch block is at least partly a functional or neurogenic disturbance. At a certain critical heart rate the impulses enter the affected bundle in its refractory phase and are thus blocked. These views are in accordance with the animal experiments of Baschmakoff (1930) who demonstrated that if one bundle was cut in such a way that only a few fibres remained intact, impulses were conveyed satisfactorily by the injured bundle as long as the heart rate was slow, but failed to cope with faster rates, which therefore gave rise to bundle-branch block.

It seems reasonable to postulate that there are at least three mechanisms by which bundle-branch block may be produced. First, it may be due to anatomical and pathological severance as demonstrated by early animal experiments and confirmed by histological studies in man (Rosenman, Pick, and Katz, 1950; Lev, 1960). Secondly it may be due to ventricular enlargement and strain with dilatation of the appropriate chamber. This is well recognized in right bundle-branch block due to right ventricular hypertrophy (Braunwald et al., 1956) and is probably also true for left-sided lesions (Master et al., 1940; Rasmussen and Moe, 1948). Thirdly, bundle-branch block may result from functional or neurogenic depression of conduction with or without underlying pathological changes. The appearance and disappearance of bundle-branch block in relation to slight modifica- 
tions in the heart rate induced by respiration, carotid sinus pressure, and changes in posture suggest that a temporary functional disturbance may be responsible for the conduction defect.

\section{SUMMARY}

Bundle-branch block can no longer be considered to result always from a discrete pathological lesion permanently interrupting the ventricular conducting system. Many instances of transient and intermittent bundle-branch block have been reported and the factors responsible for the induction and abolition of conduction defects have been reviewed.

Five patients are reported in whom bundle-branch block could be made to appear and disappear at will: in four this variation was clearly associated with alterations in the heart rate induced by respiration, carotid sinus stimulation, or pharmacological agents.

The importance of this observation in the diagnosis of myocardial infarction complicated by left bundle-branch block is discussed. It is recommended that an attempt to re-establish normal conduction should be a routine procedure in patients with left bundle-branch block.

Dr. P. A. Valentine, Fellow in Cardiology, Sydney Hospital, helped in the investigation of Case 1. This work was undertaken while the author was in receipt of a Post-Graduate Medical Foundation Grant, University of Sydney.

\section{REFERENCES}

Baker, B. M. (1930). The effect of cardiac rate and the inhalation of oxygen on transient bundle branch block. Arch. intern. Med., 45, 814.

Barker, P. S., Johnston, F. D., and Wilson, F. N. (1943). The effect of quinidine upon sinus tachycardia, including the production of transient bundle branch block. Amer. Heart J., 25, 760.

Baschmakoff, W. I. (1930). Die Bedingungen eines vollständigen funktionellen Herzblocks. Pflügers Arch. ges. Physiol., 224, 167.

Bauer, G. E. (1964). Bundle branch block, some usual and some unusual features. Aust. Ann. Med. In the press. Bergquist, N., and Hällen, J. (1956). Transitory bundle branch block. Acta med. scand., 156, 231.

Black, J. W., and Stephenson, J. S. (1962). Pharmacology of a new adrenergic beta-receptor blocking compound (nethalide). Lancet, 2, 311.

Braunwald, E., Donoso, E., Sapin, S. O., and Grishman, A. (1956). Right bundle branch block. Hemodynamic, vectorcardiographic and electrocardiographic observations. Circulation, 13, 866.

Carter, E. P., and Dieuaide, F. R. (1923). Recurrent complete heart block with normal conduction between attacks. Bull. Johns Hopk. Hosp., 34, 401.

Comeau, W. J., Hamilton, J. G. M., and White, P. D. (1938). Paroxysmal bundle branch block associated with heart disease. Amer. Heart J., 15, 276.

Daniélopolu, D., and Danulesco, V. (1921). Lésions latentes des branches du faisceau auriculo-ventriculaire: moyens de les deceler. Arch. Mal Coeur, 14, 529.

Dressler, W. (1959). Transient bundle branch block occurring during slowing of the heart beat and following gagging. Amer. Heart J., 58, 760 .

Eichert, H. (1946). Transient bundle branch block associated with tachycardia, Amer. Heart J., 31, 511.

Eppinger, H., and Rothberger, C. J. (1909). Zur Analyse des Elektrokardiogramms. Wien. klin. Wschr., $22,1091$.

-, and - (1910). Ueber die Folgen der Durchscheidung der Tawaraschen Schenkel des Reizleitungssystems. Z. klin. Med., 70, 1.

Hallhagen, K. (1961). The prognostic significance of unstable bundle branch block. Acta med. scand., 169, 509.

Herrmann, G., and Ashman, R. (1931). Partial bundle-branch block; A theoretical consideration of transient normal intraventricular conduction in the presence of apparently complete bundle-branch block. Amer. Heart J., 6, 375.

Lev, M. (1960). The anatomic basis for disturbances in conduction and cardiac arrhythmias. Progr. cardiovasc. Dis., 2, 360.

Levine, H. D. (1960). Value of critical slowing of heart in assessing co-existence of infarct with bundle branch block: an exercise in electrocardiography. Dis. Chest, 38, 187.

Lewis, T. (1913). Certain physical signs of myocardial involvement. Brit. med. J., 1, 484.

-, and Rothschild, M. A. (1915). The excitatory process in the dog's heart: Part II. The ventricles. Phil. Trans. $B, 206,181$.

Master, A. M., Kalter, H., Dack, S., and Jaffe, H. L. (1940). The relation between bundle branch block and cardiac enlargement. Amer. Heart J., 20, 186.

Mathewson, G. D. (1913). Lesions of the branches of the auriculo-ventricular bundle. Heart, 4, 385.

Mentzingen, A. von (1934). U Uber einen Fall von funktionellem Verzweigungsblock. Klin. Wschr., $13,1158$.

Miller, P. B. (1962). Myotonic dystrophy with electrocardiographic abnormalities. Amer. Heart J., 63, 704.

Packard, J. M., and Graybiel, A. (1950). Bundle branch block as a temporary phenomenon in thyrotoxicosis. Amer. Heart J., 39, 144.

Rasmussen, H., and Moe, T. (1948). Pathogenesis of left bundle branch block. Review of the literature. Brit. Heart J., 10, 141.

Rosenman, R. H., Pick, A., and Katz, L. N. (1950). Intraventricular block. Arch. intern. med., 86, 196. 
Sandberg, A. A., Wener, J., Master, A. M., and Scherlis, L. (1951). Intermittent and transient bundle branch block. Ann. intern. Med., 35, 1085.

Shearn, M. A., and Rytand, D. A. (1953). Intermittent bundle branch block. Observations with special reference to the critical heart rate. Arch. intern. Med., 91, 448.

Somerville, W., and Wood, P. (1949). Cardiac infarction with bundle branch block. Brit. Heart J., 11, 305.

Vesell, H. (1941). Critical rates in ventricular conduction. Unstable bundle branch block. Amer.J. med. Sci., 202, 198 .

Wallace, A. G., and Laszlo, J. (1961). Mechanisms influencing conduction in a case of intermittent bundle branch block. Amer. Heart J., 61, 548.

Wilson, F. N., Johnston, F. D., Rosenbaum, F. F., Erlanger, H., Kossmann, C. E., Hecht, H., Cotrim, N., Menezes de Oliveira, R., Scarsi, R., and Barker, P. S. (1944). The precordial electrocardiogram. 'Amer. Heart J., $27,19$. 